\title{
УДОСКОНАЛЕННЯ ПРОГРАМ 3 НАВЧАЛЬНИХ ДИСЦИПЛІН - ШЛЯХ ДО ПОЛІПШЕННЯ ОРГАНІЗАЦІЇ ПРАКТИЧНОЇ ПІДГОТОВКИ ЛІКАРІВ
}

\author{
І. С. Вітенко ${ }^{1}$, І. В. Мельник ${ }^{1}$, Б. В. Мельник ${ }^{2}$ \\ ${ }^{1}$ Центральний методичний кабінет з вищої медичної освіти МОЗ України, \\ ${ }^{2}$ Ірпінська центральна міська лікарня
}

\section{IMPROVEMENT OF PROGRAMS ON EDUCATIONAL DISCIPLINES - THE WAY TO ORGANIZATION IMPROVEMENT OF DOCTORS' PRACTICAL TRAINING}

\author{
I. S. Vitenko' ${ }^{1}$ I. V. Melnyk ${ }^{1}$, B. V. Melnyk ${ }^{2}$ \\ ${ }^{1}$ Central Methodical Cabinet on Higher Medical Education of MPH of Ukraine, \\ ${ }^{2}$ Irpin Central City Hospital
}

\begin{abstract}
У статті зазначаються причини частого внесення змін до Типових навчальних програм, наголошується на необхідності врахування при підготовці лікарів первинної ланки надання медико-профілактичної допомоги питань медичної етики.

The article adduces the causes of frequent changes into typical educational programs, the necessity of taking into account the primary link of providing the medical and prophylactic care at doctors' training and the issues of medical ethic.
\end{abstract}

Вступ. Стан здоров'я населення $є$ визначальним критерієм розвитку країни, адже його високий рівень $€$ передумовою економічного, соціального і політичного благополуччя в державі, запорукою безпеки і прогресу.

У цих умовах медична освіта виступає як один із регуляторів соціального розвитку, отже вона, по суті, формує доктрину життєздатності суспільства та підтримує його через діяльність кадрів системи охорони здоров'я. Рівень ефективності та якості використання медичних кадрів, безумовно, залежить не лише від рівня їх теоретичної та практичної професійної підготовки, а й від низки набутих суто людських позитивних моральних якостей, без яких не може відбуватися становлення медика: чуйності, доброти, милосердя, чесності, комунікабельності, готовності до самопожертви [1].

Основна частина. Лікар - єдина професія, в якій випускник вищого навчального закладу, отримавши диплом, не має права самостійно працювати.

У 2011 році відбувся перший випуск лікарів, які навчались за новим навчальним планом підготовки фахівців освітньо-кваліфікаційного рівня "спеціаліст" за спеціальностями “Лікувальна справа", "Педіатрія", "Медико-профілактична справа", побудованим за

() І. С. Вітенко, І. В. Мельник, Б. В. Мельник
Європейською кредитно-трансферною системою (ECTS) організації навчального процесу (затверджений та введений наказом МО3 України від 31.01.2005 № 52). Як зазначено в пояснювальній записці до вказаного навчального плану, тижневе аудиторне навантаження студента становить в середньому 25 - 28 годин, обсяг самостійної роботи складає, в середньому, 40 \% від загального, що відповідає вимогам Болонського процесу [2]. Це, у свою чергу, викликало дуже багато нарікань викладачів, перш за все, клінічних кафедр і є однією з причин того, що засади Болонської декларації впроваджуються у вищу медичну освіту не просто.

Разом 3 тим, після внесення змін до зазначеного навчального плану на виконання Постанови Кабінету Міністрів України від 26 липня 2006 p. № 1025 “Про заходи щодо оптимізації мережі військових навчальних підрозділів вищих навчальних закладів", у доопрацьованому навчальному плані підготовки лікарів, затвердженому наказом МО3 України від 23.07.2007 № 414, було суттєво збільшено кількість навчальних годин для викладання дисциплін циклу професійної підготовки, перш за все клінічних, а також збільшено частку аудиторних годин для вивчення найбільш важливих для професійного становлення лікаря дисциплін. 
Окрім того, Міністерством охорони здоров'я на виконання наказів МОН України від 09.07.2009 № 642 "Про організацію вивчення гуманітарних дисциплін за вільним вибором студента” та від 29.03.2010 № 259 "Про внесення змін до наказів МОН від 09.07.2009 № 642 та від 21.12.2009 № 1150” було повторно внесено зміни і до навчального плану дипломної підготовки лікарів, затвердженого наказом МO3 України від 23.07.2007 № 414. Таке часте внесення змін до навчальних планів призвело до необхідності вносити корективи і до затверджених МО3 України типових програм $з$ дисциплін. Разом з тим, Міністерством охорони здоров'я України, за пропозицією фахівців робочої групи МО3 України по запровадженню положень Болонської декларації у навчальний процес вищих медичних (фармацевтичного) навчальних закладів (затверджена наказом МO3 України від 04.12.2008 № 721), в оновлених навчальних планах знову було додатково збільшено кількість аудиторних годин для вивчення клінічних дисциплін, зроблено їх перерозподіл залежно від спеціальності (табл. 1).

Таблиця 1. Навчальні плани, затверджені наказами МОЗ України

\begin{tabular}{|c|c|c|c|}
\hline \multirow{2}{*}{$\begin{array}{l}\text { Дисципліни, } \\
\text { спеціальність }\end{array}$} & \multicolumn{3}{|c|}{ Час затвердження } \\
\hline & $\begin{array}{l}\text { від 19.10.2009 № 749, } \\
\text { від 08.07.2010 № 539 }\end{array}$ & від 23.07.2007 № 414 & від 31.01.2005 № 52 \\
\hline $\begin{array}{l}\text { Внутрішня медищина } \\
\text { - Лікувальна справа } \\
\text { - Педіатрія } \\
\text {-Медико-профілактична } \\
\text { справа }\end{array}$ & $\begin{array}{c}1080 \text { (780 ауд.) } \\
735 \text { (510 ауд.) } \\
795 \text { (550 ауд.) }\end{array}$ & $\begin{array}{l}990 \text { (750 ауд.) } \\
765 \text { (500 ауд.) } \\
765 \text { (530 ауд.) }\end{array}$ & $\begin{array}{l}945 \text { (730 ауд.) } \\
720 \text { (480 ауд.) } \\
720 \text { (510 ауд.) }\end{array}$ \\
\hline $\begin{array}{l}\text { Педіатрія } \\
\text { - Лікувальна справа } \\
\text { - Педіатрія } \\
\text { - Медико-профілактична } \\
\text { справа }\end{array}$ & $\begin{array}{c}570 \text { (410 ауд.) } \\
1005 \text { (760 ауд.) } \\
450 \text { (340 ауд.) }\end{array}$ & $\begin{array}{l}540 \text { (390 ауд.) } \\
765 \text { (610 ауд.) } \\
405 \text { (305 ауд.) }\end{array}$ & $\begin{array}{l}540 \text { (330 ауд.) } \\
765 \text { (580 ауд.) } \\
405 \text { (275 ауд.) }\end{array}$ \\
\hline $\begin{array}{l}\text { Хірургія } \\
\text { - Лікувальна справа } \\
\text { - Педіатрія } \\
\text { - Медико-профілактична } \\
\text { справа }\end{array}$ & $\begin{array}{l}705 \text { (450 ауд.) } \\
600 \text { (400 ауд.) } \\
555 \text { (350 ауд.) }\end{array}$ & $\begin{array}{l}675 \text { (420 ауд.) } \\
675 \text { (420 ауд.) } \\
540 \text { (310 ауд.) }\end{array}$ & $\begin{array}{l}630 \text { (400 ауд.) } \\
630 \text { (400 ауд.) } \\
495 \text { (310 ауд.) }\end{array}$ \\
\hline
\end{tabular}

Таким чином, згідно з діючими навчальними планами підготовки фахівців освітньо-кваліфікаційного рівня “спеціаліст” кваліфікації “лікар” у вищих медичних навчальних закладах IV рівня акредитації за спеціальностями "Лікувальна справа", "Педіатрія", “Медико-профілактична справа”, затвердженими наказами МОЗ України від 19.10.2009 № 749 та від 08.07.2010 № 539, для самостійної роботи студентів з опанування клінічних дисциплін передбачено приблизно 30 \% навчальних годин. Наприклад, для спеціальності “Лікувальна справа": 3 "Внутрішньої медицини" - 28\% \%, “Педіатріі”"-28\%, “Хірургіï”-36\%, “Акушерства і гінекології” - 30\%, “Онкології”- 28 \%; для спеціальності "Педіатрія" : 3 "Внутрішньої медицини”- 30 \%, “Педіатріі”- 24 \%, “Хірургіi”'-30%, “Акушерства і гінекологї” - $33 \%$.

Як зазначалось вище, наведені у таблиці зміни до навчальних планів приводять до необхідності вносити корективи до типових навчальних програм з багатьох дисциплін. Це, в свою чергу, є додатковим навантаженням на фахівців опорних кафедр, визначених наказом МОЗ України від 23.08.2011 № 532.
У лютому - березні 2011 р. Центральним методичним кабінетом з вищої медичної освіти доручено фахівцям опорних кафедр внести зміни до 75 типових навчальних програм, затверджених MO3 України протягом 2006-2011 pp.

Доопрацьовуючи програми, розробники повинні врахувати накопичений ними досвід викладання дисципліни і внести зміни не тільки до розподілу навчальних годин, але й до змісту програми.

При організації викладання клінічних дисциплін, а особливо при впровадженні Наскрізної програми підготовки студентів медичних факультетів та лікарівінтернів для оволодіння практичними навичками та методиками, необхідними для роботи на посадах лікарів за спеціальністю “Загальна практика - сімейна медицина”, підготовленої на виконання доручення Кабінету Міністрів України від 23 листопада 2010 р. № 69/158/1/1-10 до доручення Президента України від 19 листопада 2010 р. № 1-1/2753 “Щодо реформування системи охорони здоров' я, спрямованого на підвищення якості і доступності медичної допомоги для громадян України” та наказу МО3 України від 
03.12.2010 № 1074 “Про заходи МОЗ України щодо удосконалення підготовки лікарів", доцільно врахувати частоту звернень до лікарів первинної ланки медико-профілактичної допомоги хворих з тією чи іншою патологією. На прикладі Гостомельської поліклініки (Ірпінська центральна міськалікарня Київської області), яка обслуговує 16341 жителів приміської зони м. Києва, у 2011 році було 48239 звернень до лікарів, 3 них 3 приводу хронічних захворювань -27336 (у тому числі 3 приводу хвороб ендокринної системи - 30 \% (у т. ч. цукрового діабету $-46 \%$ ), захворювань нервової системи - $28 \%$, захворювань серцево-судинної системи $-21 \%$, захворювань органів дихання $-13 \%$, органів травлення $-5 \%$, хвороб крові - 0,2 \%). При цьому загальна захворюваність дорослого населення на 10 тис. населення становить: новоутворення - 390,0; цукровий діабет - 337,9; гіпертонічна хвороба - 2286,9; інфаркт міокарда - 7,8; ішемічна хвороба серця 1671,8 ; бронхіальна астма - 38,9; виразкова хвороба240,7; гастрит та дуоденіт - 393,8 (2010 рік).

При підготовці студентів до їхньої майбутньої професійної діяльності необхідно також враховувати існуючі тепер реальні економічні умови функціонування медичних закладів первинної ланки надання медичної допомоги населенню України. У багатьох ситуа-

\section{Література}

1. Панорама охорони здоров'я населення / за ред. А. В. Підаєва, О. Ф. Возіанова, В. Ф. Москаленка. - К. : Здоров'я, 2003.-С. 159.

2. Підаєв А. В. Болонський процес в Свропі. Що таке і чи потрібний він Україні? Чи можлива інтеграція медичної освіти України в Європейський освітній простір? / А. В. Підаєв, В. Г. Передерій. - Одеса : Одес. держ. мед. ціях комунікативні відносини лікаря та пацієнта є визначальними у вирішенні багатьох організаційних питань надання допомоги хворим, що звертаються у поліклінічні установи. Тому в оновлених освітньо-професійних програмах спеціаліста галузі знань 1201 "Медицина" за усіма спеціальностями мають бути обов'язково збережені навчальні години для вивчення питань медичної етики та деонтології.

Лікарі повинні вміти аналізувати передконфліктні і конфліктні ситуації (шифр ГО 001), визначати індивідуально-психологічні відмінності особистості за їхніми проявами у діяльності та спілкуванні (шифр ГО 006), визначати роль соціальних та соціально-психологічних чинників у розповсюдженні хвороб (шифр ГО 010); використовувати принципи моралі, враховувати національні та релігійні особливості для виконання професійних функцій (шифр ГО 013); демонструвати розуміння нормативно-правового регулювання взаємовідносин лікар-хворий (шифр ГО 021) і застосовувати моральні, етичні та фахові норми в професійній діяльності (шифр ГО 025) [3].

Висновок. Таким чином, при організації додипломної підготовки лікарів необхідно враховувати всі аспекти їх подальшої практичної діяльності в реальних умовах сьогодення.

ун-т, 2004. -190 с.

3. Складові галузевих стандартів вищої освіти напряму підготовки 1101 "Медицина" освітньо-кваліфікаційного рівня “спеціаліст" за спеціальностями: 7.110101 "Лікувальна справа”, 7. 110104 “Педіатрія”, 7.110105 “Медико-профілактична справа”. -К., 2002.-369 с. 